\title{
PERFORMANCE FACTORS OF CZECH COMPANIES IDENTIFIED USING STATISTICAL PATTERN RECOGNITION: INTERPRETATION OF RESULTS
}

\section{Ondřej Částek}

\begin{abstract}
The paper interprets factors of corporate performance identified by means of statistical pattern recognition techniques. A Dependency-Aware Feature algorithm with non-linear regression model ranked 74 potential factors of corporate performance according to their contribution to corporate performance prediction. This paperbrings consecutivestatisticalanalyses, which interpret theeffects of Strategy, FDI, Share of Export, Top Management Performance Pay, and Workers' Performance Pay on corporate performance. Furthermore, the analyses reveal strong mutual moderating interdependencies. On the national scale, the paper brings evidence that the companies from the industries researched can use the stational techniques to learn about corporate performance factors. On a global scale, the paper introduces the contribution of Dependency-Aware Feature selection in the field of management and confirms the need for a multidimensional contingency approach in researching corporate performance. The results are based on a sample of 432 private limited or joint stock companies located in the Czech Republic operating in the manufacturing and construction industries and employing 50 or more people.
\end{abstract}

Keywords: corporate financial performance, statistical pattern recognition, dependency-aware feature selection, factors of corporate performance, strategy, FDI

JEL Classification: L25, M10

\section{Introduction}

The search for factors of performance or competitiveness of companies is a topical and attractive task, drawing the attention of a wide range of authors. One can list a number of works not only from the Czech and Slovak environment, but also from worldwide publications. At the same time, finding performance factors is a very difficult task. Scholars have not yet come to a clear consensus on how business performance should be measured, too many characteristics are regarded as potential factors of performance, and the methods commonly used to measure relationships between factors and performance have a number of limitations. This article aims to present and interpret the results of two related research projects: the Search for Factors of Czech Companies' Competitiveness conducted by the Research Centre for Competitiveness

* Ondřej Č́stek, Faculty of Economics and Administration, Masaryk University, Brno, Czech Republic (castek@econ.muni.cz).

The author is grateful for the support by the Grant Agency of the Czech Republic - Project No. P403/12/1557. Also, the author is thankful for language help and proof reading by Mgr. et Mgr. Bc. Milan Boháček, M.A. and Steven Del Riley, BA and for helpful suggestions by two anonymous reviewers. 
of the Czech Economy (RCCCE) ${ }^{1}$, and Developing Methods for Identifying and Evaluating Factors That Critically Affect Corporate Performance conducted with the support of the Grant Agency of the Czech Republic (GACR)2.

The original research project carried out by the RCCCE was exploratory by its nature. It aimed to identify competitiveness factors of Czech companies, and one of its outcomes was a database comprising 432 companies described with almost five hundred variables (see for details Blažek et al., 2008). The latter project aimed at "Developing Methods for Identifying and Evaluating Factors that Critically Affect Corporate Performance". Its main outcome was an original Dependency-Aware Feature (DAF) algorithm, which together with a nonlinear regression model ranked potential factors of corporate performance according to their informativeness, i.e. according to their ability to predict corporate performance. The paper by Somol et al. (2014) brings the list of 25 most informative variables, and an insight into the DAF functioning, while Pudil et al. (2014) provide an in-depth explanation of the DAF algorithm, its results, and an interpretation of these results through a series of linear regression analyses and cluster analyses.

This work offers further analyses. The previous works evidenced strong mutual interdependencies among the potential and actual factors (predictors) of corporate performance (e.g. Částek et al., 2013) suggesting potential moderating effects. In this paper, the potential moderating effects are approached as a set of implicit hypotheses. The approach to their formulation and testing will be explained in Section 2. Methodology and the results and their interpretation can be found in the subsequent chapters.

It is not easy to position the topic of this paper inside one field within management. It certainly belongs to the business research area, but because of the exploratory nature of the basal (RCCCE) research project, the potential performance factors originally spread out from stakeholder importance through the subjective evaluation of tangible assets to the corporate social responsibility activities. However, here we focus on the five most informative factors, which include FDI, Export, Top Management Performance Pay, Workers' Performance Pay and Strategy. This directs us into the fields of strategic management, human resources management and international management.

It would be demanding in terms of space to review literature relevant to all of the aforementioned fields. The reader can kindly refer to the book by Blažek et al. (2007) and working papers ${ }^{3}$, where the choice of potential performance factors was originally justified. In this paper, the literature review is supplemented to a certain degree in the Discussion where the results are confronted with appropriate works.

The research question of the RCCCE Project "What Are the Factors of Czech Companies" Performance?" was answered sufficiently. However, another question of "How Do These Factors Influence the Corporate Performance?" remains open (see the justification below in Section 2.2. Methods: Statistical Tools), and answering this question is the goal of this work.

\footnotetext{
1 More information available in Czech here: https://www.econ.muni.cz/vyzkum/resene-projekty/3374

2 This work has been supported by the Czech Science Foundation (GA ČR) - Project No. P403/12/1557.
}

3 No. 9/2005-14/2005, published by RCCCE. 
In order to achieve this goal, the reader will be briefly introduced to the topic researched, approach chosen to evaluate business performance and to the method for evaluating the relationships between factors and performance of businesses, which was developed by the latter of the above-mentioned studies. Subsequently, data utilized from the former of the above-mentioned studies will be described, and finally, the results and their interpretation will be presented.

\section{Methodology}

As was explained above, the author extends two previous projects. Both of them were exploratory by their nature, with no prior hypotheses in the statistical sense. However, the statistical hypotheses were not formulated in advance due to the lack of evidence in the field of corporate performance; on the contrary, an extensive body of literature can be found on corporate performance factors. In general, these factors are not mutually independent, and therefore they have to be selected in a multidimensional space. Taking into account their potential synergetic effect and mutual interdependencies, the result would have been such a high number of potential hypotheses that it would have been impossible to include them in one comprehensive model. For this reason the second project aimed at "Developing Methods for Identifying and Evaluating Factors that Critically Affect Corporate Performance", and one of its outcomes was a list of 74 variables ranked according to their ability to predict corporate performance. Here, the nature changes from exploratory to explanatory research. The author processes the top five variables, i.e. corporate performance factors, best predicting corporate performance, with the tools traditionally used in the confirmatory research design. Still, the reader can see in the section on data description that the number of hypotheses needed for statistical testing would be enormous. Therefore, a set of general hypotheses will be tested. The first set of hypotheses will test the individual zero-order relationship of the five chosen variables to the corporate financial performance (CFP). An example of such a hypothesis is $\mathrm{H}_{1}$ : Presence of foreign direct investment in a company has an effect on corporate financial performance with a null hypothesis $\mathrm{H}_{0}$ : Corporate financial performance shows no difference between the companies with FDI and without FDI. The second and larger set of hypotheses tests the higher-order moderating effects (up to the fourth order) on the zero order relationships. A general hypothesis would be $\mathrm{H}_{\text {mod }}$ : Under what circumstances does particular factor influence the corporate financial performance, with an example of a particular hypothesis $\mathrm{H}_{\bmod 1}$ : There is a difference of the FDI effect on CFP between exporting and non-exporting companies with a null hypothesis $\mathrm{H}_{\bmod 0}$ : There is no difference of the FDI effect on CFP between exporting and non-exporting companies. Higher-order hypotheses than combine the moderating effects of other variables.

\subsection{Methods: Corporate Performance}

Hult, Ketchen, Griffith, Chabowski, Hamman, Dykes, Pollitte, and Cavusgil (2008) examine articles from prestigious journals, in which some form of measuring corporate 
performance was used, and they divide the individual measurement procedures into three areas: financial performance, operating performance and overall effectiveness performance. The financial performance measurement is often used in cases similar to ours offering the possibility of objective evaluation easily workable in quantitative research, especially if the focus is on the accounting measures category. The obvious disadvantages are historical perspective and possible misrepresentation of data by businesses for tax optimization. Richard, Devinney, Yip, and Johnson (2009) look at the accounting measures more closely and identify 20 different measures. When choosing the most appropriate one, one must consider the specifics of the area, which the study focuses on as well as the country which they are to be used in (therefore, e.g. market measures are not suitable for the Czech Republic). Work by Sedláková (2014) can serve as a recent example from the Czech and Slovak environment focussing on the usefulness of bankruptcy prediction models for practice in Slovakia. Harumová and Janisová (2014) apply scoring functions to assess performance of Slovak enterprises. Both works, however, assess companies with models that use a larger number of variables, which is not suitable for quantitative research in terms of operationalization. A specialized study by Šiška and Lízalová (2011) provides evidence that a combination of return on sales and revenue growth is most appropriate for the Czech Republic. Due to the easier availability of data, this research uses ROA and growth of assets (GA); Pokorná and Ćástek (2013) show that the best way to combine them is the sum of these two indicators. In this particular application, ROA and growth of assets were standardised into $z$-scores before they were summed up.

\subsection{Methods: Statistical Tools}

Regarding the methods used to evaluate the relationships between factors of corporate performance and performance itself, Andrews (2010) uses correlations, Artiach (2010) $t$-tests and other studies employ a number of different methods investigating the connection between two or several variables. However, the key assumption of this article that corporate performance depends on many factors and their effects must be examined in context is more in line with studies using multiple linear regression (e.g. Cagwin, 2006), multiple logistic regression (e.g. Kessler, 2007), structural modelling (e.g. Yilmaz, 2005), or decision trees (e.g. Molina, 2004). However, these methods have limitations based on assumptions concerning linearity, the ratio of the number of predictors to the number of observations, requirements for an a priori model, or nature of variables, among others. Špalek and Částek (2010) present the use of the SFFS algorithm and $k$ NN method to eliminate the deficiencies listed. The combination was subjected to further testing within the second research project mentioned above, called Developing Methods for Identifying and Evaluating Factors That Critically Affect Corporate Performance, and the result is a combination of the Dependency-Aware Feature algorithm with a nonlinear regression model. Pudil et al. (2014) provide details. In short, the DAF method is a feature selection method meaning that its algorithm aims to select those features which are the most informative according to a given criterion. In other words, the task starts with many features describing objects that are divided into classes. Then, only some features can 
be responsible for classification of an object into a specific class (classes can be substituted by an interval variable - see below). The DAF method evaluates the contribution of an individual feature to the correct classification of the objects. This feature contribution is referred to as the informativeness of such a feature. In this particular application, companies represent the objects, potential factors of CFP are the features, and CFP (e.g. ROA + GA) is the class information (used for the sake of simplicity as one class "above-average performing companies" and another class "below-average performing companies"). Therefore, the DAF method selects those potential factors of CFP that carry most information for determining the CFP. Two important notes are: a) the DAF method does not really select, as for example the SFFS algorithm did (see Špalek and Částek, 2010), but rather ranks the features according to their informativeness, and $b$ ) the DAF method does not evaluate the individual informativeness of a feature, but evaluates "the average feature ability to improve the criterion value on addition to a subset, evaluated over a large number and variety of contexts (various subsets)" (Somol et al., 2014). Therefore, DAF respects the assumption of mutual dependency of features, which, for example, would be regarded as multicollinearity prohibiting the use of multiple regression. The above-mentioned nonlinear regression model serves as a mean of evaluating the informativeness of a feature or subset of features. The most informative features minimize an estimated error of predicted dependent values for each known company. Again, the non-linear regression model can be compared to the $k N N$ classifier used earlier (Špalek and Č́stek, 2010) together with the SFFS algorithm. However, the $k \mathrm{NN}$ classifier requires a definite number of mutually exclusive classes, for example "above-average performing companies" and "under-average performing companies", which reduces the information contained in a measure computed as ROA + GA. The regression model works with an interval variable, which means higher accuracy in CFP measurements. Nevertheless, the non-linear regression model does not provide any information about how the selected (or more precisely ranked) features influence the dependent variable; such an explanation is the objective of this paper.

\subsection{Data}

The utilized data come from a unique questionnaire survey in terms of its extent conducted during 2007 by the Research Centre for the Competitiveness of the Czech Economy at the Faculty of Economics and Administration at Masaryk University from the Albertina database, and from other public databases, which provided information about the financial performance of the companies in years 2004-2010.

The population of the surveyed companies was based on the following criteria: private limited companies and joint stock companies based in the Czech Republic operating in the manufacturing and construction industries and employing 50 or more people. After excluding companies in the stage of liquidation, bankruptcy or judicial execution, the set included 4,483 subjects at the time of the empirical investigation, 2,817 of which had the required level in terms of comprehensiveness and quality of financial information. This set became the population for the research in question. The population was first addressed through e-mail, then with a letter and further their willingness to cooperate on the survey 
was supported by a phone call. The empirical survey took place in 2007 and produced data about 432 companies, which represents $15.33 \%$ of the population. Reliability and validity of the data was achieved through a small-sample pilot study as well as interviewing statutory representatives of the companies by a small number of professional interviewers, who were trained for this particular purpose. More details and proof of representativeness are included in Blažek et al. (2007, pp. 27-34).

Corporate performance should be perceived, among other things, as a long-term issue. Competitive advantage causing corporate performance should therefore be sustainable (cf. Reed, DeFillippi, 1990). That is one of the reasons why corporate performance should also be measured in the long term. Another reason, especially if using financial indicators is the long-term approach, is that it helps to reduce random fluctuations or deliberate distortions in the reported performance. For instance, Kirby (2005) identifies a suitable period of ten years. Other authors are satisfied with shorter periods. For instance, Artiach (2010) and Hansen (1989) suggest five years, or Abor (2007) six years. A seven-year series of data from 2004-2010 is used in this case. A series longer than the five years allows accepting up to two missing values in financial data, and therefore the ability to evaluate the financial performance of a larger number of companies that participated in the empirical investigation.

The questionnaire provided a wide range of variables describing the participating companies (the result of the RCCCE Project); 74 of them entered further experiments. The DAF algorithm in combination with a non-linear regression model analysed their informativeness (see Section 2.2. Statistical Tools). Somol et al. (2014, pp. 282-283) list the 25 most informative variables (the result of the GA CR Project). Because of limited space, the effect of only the top five ones is analysed and interpreted below. The following table explains their meaning.

Table 1 | Most Informative Variables: Their Character and Meaning

\begin{tabular}{|l|l|c|}
\hline Variable & \multicolumn{1}{|c|}{ Description } & Measure \\
\hline FDI & $\begin{array}{l}\text { The presence of foreign capital measured with foreign capital } \\
\text { or without foreign capital (Yes/No) }\end{array}$ & Nominal \\
\hline Export & Does the company export or not (Yes/No) & Nominal \\
\hline $\begin{array}{l}\text { Top Management } \\
\text { Performance Pay }\end{array}$ & $\begin{array}{l}\text { Share of variable outcomes-based compensation of top } \\
\text { management on their fixed pay }\end{array}$ & Interval \\
\hline $\begin{array}{l}\text { Workers' } \\
\text { Performance Pay }\end{array}$ & $\begin{array}{l}\text { Share of variable outcome-based compensation of workers } \\
\text { on their fixed pay }\end{array}$ & Interval \\
\hline $\begin{array}{l}\text { Strategy } \\
\text { Corporate strategy defined as Cost Leadership, Cost Focus, }\end{array}$ & Nominal \\
\hline
\end{tabular}

Source: Author's calculations.

Originally, the Export variable measured the share of exports on sales but due to a significantly skewed distribution (many companies did not export at all) it was transformed into a dichotomous variable. 
The Strategy variable was defined through Porter's generic strategies with four values listed in the table above. The reader can note below that dummy variables Strategy: Focus Yes/No and Strategy: Cost/Differentiation are used as well. While this makes the analyses more complicated, the results show that such distinctions have a substantial effect in some cases.

\section{Results and Discussion}

Not all factors are statistically significant at the zero-order relationships: only Export and Strategy do. As regards the strength of the relationship, regardless of the impact of other factors, the Strategy has a closer relationship with financial performance. In any case, the relationship is weak in both cases.

Table 2 | Most Informative Variables: Their Zero-Order Effect on Corporate Financial Performance

\begin{tabular}{|l|c|c|c|c|}
\hline Variable & Coefficient & Effect size & $\mathbf{p}$ (two-tailed) & $\mathbf{N}$ \\
\hline FDI Yes/No & $\eta$ & - & n.s.s & 350 \\
\hline Export: Yes/No & $\boldsymbol{\eta}$ & $\mathbf{0 . 1 2}$ & $\mathbf{0 . 0 3}$ & $\mathbf{3 7 9}$ \\
\hline Top Management Performance Pay & $r_{s}$ & -0.02 & 0.77 & 348 \\
\hline Workers' Performance Pay & $r_{s}$ & 0.07 & 0.19 & 348 \\
\hline Strategy & $\boldsymbol{\eta}$ & $\mathbf{0 . 1 5}$ & $\mathbf{0 . 0 4}$ & $\mathbf{3 5 3}$ \\
\hline Strategy: Focus Yes/No & $\boldsymbol{\eta}$ & $\mathbf{0 . 1 3}$ & $\mathbf{0 . 0 1}$ & $\mathbf{3 5 3}$ \\
\hline Strategy: Cost/Differentiation & $\eta$ & - & n.s.s. & 353 \\
\hline
\end{tabular}

Source: Author's calculations.

The aforementioned text quantifies the zero-order relationships. However, they may be only spurious, or conversely, where none were found, these relationships may be of a nonlinear shape. Another possibility is they may be moderated by a third variable the other variables mentioned above are highly likely moderating variables. In accordance with the approach to examining the success of different strategies (see Section 3.5. of the paper), one can call them contingency variables. An example might be a relationship of FDI and CFP, which is not present at the level of the zero-order relationship. A previous study (Č́stek, 2013) on the relationship between the ownership structure and CFP, which used similar data, demonstrated that the relationship might be a conditional one. The effect of FDI on CFP was limited here only to certain subsets of businesses (specifically, e.g. small businesses with up to 100 employees). Another example is the relationship between the importance of owners and CFP. In a 2009 study (Blažek, Částek) again using similar data, the zero-order relationship was weak in the entire sample, since the relationship was negative in the manufacturing industry and positive in the construction industry. Therefore, 
the following text will deal with the evaluation of partial, moderated and non-linear relationships employing strata based on contingency variables.

Since the Result part of this paper is very long, offers limited value added only, and serves just for the case the reader is interested in actual correlation in a particular subset, it has been situated in Appendix A (available online only). Because Strategy is the key contingency variable, other variables will now be discussed and only then Strategy and its interdependencies with these variables will follow.

\subsection{FDI}

Theory usually explains the effect of FDI in a company on its CFP as bringing in better know-how, higher investment possibilities choosing better performing companies, but also withdrawing funds (as demonstrated by banks with a foreign parent in the Czech Republic in the recent economic crisis) or profits (using transfer prices: Weiss and Nikitin, 2004) away from subsidiaries.

According to Djankov and Hoekman (2000), foreign companies invested in companies with above-average productivity in the Czech Republic, but they also further improved their productivity (data from 1992-1996). Kočenda and Švejnar (2003) analyse a "virtually complete population of medium and large firms privatized in a model large-scale privatization economy (Czech Republic)" and find concentrated foreign ownership improving corporate performance (ROA) contrary to concentrated domestic ownership (data from 1996-1999). A statistic from Zemplinerová (1997) supports this notion: companies with foreign ownership produced 11.2\% of GDP with 8.5\% of workforce in 1995 in the Czech Republic. Jurajda and Stančík (2009) limit their findings of the positive effect of foreign investments to non-exporting branches (data from 1995-2005) explaining that companies facing competition on an international scale "do not need to be disciplined by foreign owners". More recent data do not show such unequivocal evidence. Roubíčková and Heryán (2014) claim that FDI contributes to higher ROE of companies in the Czech Republic (data from 2007-2012), but the size and other characteristics of their sample are unclear. In a study by Cerovic, Stanisic, Radojevic, and Radovic (2015), a slightly positive effect of FDI on ROIC of Serbian companies turned to be distinctively negative after controlling for company size (data from 2008-2013). Back to the Czech Republic, Pokorná (2012) computes descriptive characteristics of all joint-stock companies (a.s.) and private limited companies (s.r.o.) having 50 or more employees (population $\mathrm{N}=8424$, sample $\mathrm{N}=4717$ ). During the period of 2005-2009 the median values of growth of assets and ROA in the whole sample were (statistically significantly) higher for domestic companies. When controlling for the industry, the effect was not the same in all branches. In some of them the negative effect was more pronounced, whereas in some others the effect was positive ${ }^{4}$. This finding relativizes most of the previously mentioned results. Perhaps only Kočenda and Švejnar (2003) use a research design, which allows for appropriately controlling for branch specifics. They employ distance to the Cobb-Douglas specification of production function as a measure of performance.

4 Branches with the strongest statistically significant positive effect of FDI on ROA (Pokorná, 2012):

Manufacture of other transport equipment; Electricity, gas, steam and air conditioning supply;

Activities of head offices, management consultancy activities; Employment activities. 
In this sample, the Strategy pursued moderates the effect of the presence of FDI in a company on its financial performance. This finding is consistent with the approach by Garcia-Fuentes, Ferreira, and Kennedy (2013), for example. However, this team substituted strategy with Firm Size, Marketing Intensity and Capital Intensity variables, which means that the study is not fully comparable. Unfortunately, the Czech environment does not provide research that would take strategy into consideration, when examining the effect of FDI. Consequently, from the data presented above, in the companies with the Cost Leadership strategy, which are among the least efficient in our sample, the presence of FDI is significantly positive, while in the companies pursuing the Differentiation Focus strategy, which rank among the top performers, the presence of FDI decreases their CFP. Similarly, the presence of FDI decreases CFP in companies pursuing the other strategies; however, the moderation is not so strong among these companies and the differences are not statistically significant. The group of companies with FDI contains a higher proportion of exporting businesses.

\subsection{Export}

The effect of Export on CFP can also have different explanations. Clerides, Lach and Tybout, (1998) mention "learning by exporting" (which means a spillover of technologies and other knowledge from customers or even other suppliers of these customers (World Bank, 1993). Furthermore, the exporting companies should benefit from wider markets, which translates into higher economies of scale, extended product life-cycles or the possibility to address growing markets, while domestic markets are saturated (Czinkota, Ronkainen, 1998). Saxa (2008) mentions the only negative effect, which is sunk costs. Also, Saxa (2008) offers a rare empirical insight into the relationship between the performance of Czech companies and their export activities: he does not find the effect of learning by exporting among Czech companies. Another finding, by Moini, Kalouda, and Tesar (2008), reveals that Czech exporters use a larger percentage of their production capacity. Nonetheless, neither of the last two studies use financial performance as the dependent variable.

Lee and Habte-Giorgis (2004) propose and verify (on US data) a framework for studying the effect of export activities on corporate performance. According to their model, strategy influences export activities and export activities influence (financial) performance. Also, export activities moderate the relationship between strategy and performance. This paper presents results, which are in accordance with Lee and Habte-Giorgis's (2004) model because corporate strategy modifies the effect of export on performance. Non-exporting companies pursuing the Cost Focus strategy do not differ from those that export. In the group of companies pursuing the Differentiation strategy the negative effect of Export is stronger. In the companies pursuing the remaining strategies the negative effect of Export is similarly strong as in the rest of the full sample. In companies without FDI, the effects of the Focus Yes/No and Export Yes/No on CFP aggregate. For example, companies without FDI that pursue the Focus strategies and do not export have significantly above-average CFP, while in contrast companies without FDI that export and do not pursue the Focus strategies result in significantly below average CFP. The negative effect of Export on CFP is consistent 
with the findings by Leitner and Güldenberg (2009), who report this effect for Austrian companies between 1992 and 2002. In addition to the aforementioned sunk costs, the lower CFP of exporting companies might be a result of more intensive competition on foreign markets. The usual arguments explaining the positive effect of exports work with productivity as the dependent variable. In this case, however, the financial performance measures how companies realized produced volumes on the market. Another explanation may be the transfer prices of businesses that are foreign-owned. In the group of companies that are part of a foreign concern, the CFP of non-exporting companies (i.e. companies where transfer prices cannot occur) is indeed significantly higher than in exporting companies. Upon closer inspection, a threshold can be observed in the region of $40-60 \%$ share of exports on sales. In this area of the share of export companies are more efficient than in areas up to $40 \%$ and above $60 \%$. However, the differences are not statistically significant (the size of this subset is only $\mathrm{N}=60$ ).

\subsection{Top Management Performance Pay}

An extensive body of literature examines the relationship between management remuneration and corporate performance. Two opposite effects can explain this relationship: (a) motivation, and (b) costs. In general, the overall effect does not have to be positive. Banker, Lee, Potter, and Srinivasan (1996) mention case studies evidencing both possibilities in practice. Many quantitative empirical surveys confirm the positive effect of outcome-based incentives on corporate performance (recently Upneja and Ozdemir, 2014). Authors in this field usually view the effect on financial performance as mediated through a set of specific overall performance measures, such as science harvesting and invention resonance (Makri, Lane, and Gomez-Mejia, 2006) or customer service and customer satisfaction (Banker et al., 1996). That again calls for contingency and a contextual approach. For example, Banker et al. (1996) find competition and strategic factors to significantly moderate the effect of outcome-based incentives on corporate performance. However, quantitative empirical studies on this particular problem from the Czech Republic are not available. For example, Paligorova (2007) investigates the use of outcome-based incentives for executives, but without the relationship to corporate performance.

Results of this study confirm the Banker et al. (1996) findings about contextual factors. Top Management Performance Pay affects CFP only in companies pursuing particular strategies and the direction of the effect depends just on the Strategy pursued. Therefore, not finding this effect in the whole sample does not mean that this variable does not affect CFP. Non-exporting companies pursuing the Differentiation strategy as well as exporting companies pursuing the Differentiation Focus strategy show a moderately strong and positive effect of Top Management Performance Pay on CFP; on the other hand, companies pursuing both of the Cost strategies show a negative effect, with a stronger effect in nonexporting companies and especially in non-exporting companies pursuing the Cost Focus strategy. Nevertheless, the size of the observed effect could also result from a rather low number of observations in each category $(\mathrm{N}=6-126)$. 


\subsection{Workers' Performance Pay}

Two opposite effects can also explain the relationship between flexible wages and performance: (a) a positive effect of higher effort made by workers and greater ability to hire the most productive workers (Lazear, 2000), and (b) a negative effect of higher costs due to measurement difficulties, undesirable risk transfers, quality declines (Lazear, 2000), faster fatigue (Paarsch, Shearer, 1999) or simply because costs associated with the pay-forperformance scheme are higher than revenues induced by marginal product. Most studies report a positive overall effect of flexible wages on different measures of performance (e.g. Damiani and Ricci, 2008, Gielen, Kerkhofs, and van Ours, 2010). However, Battisti and Vallanti (2013) report no effect of flexible wages on the effort of blue-collar workers, Frick, Goetzen, and Simmons (2013) report mixed effects - a lower rate of absenteeism but also lower quality after introducing performance pay, and Paarsch and Shearer (1999) empirically confirm the above-mentioned faster fatigue and quality issues connected with piece rates. Unfortunately, quantitative empirical studies from the Czech environment are not available. Botek and Pecháčová (2013) theoretically justify that rewards must be fair, while Hradecká (1995) describes the remuneration methods used in the Czech Republic without a relationship to any performance measure, and Venclová, Königová, and Fejfar (2013) describe appraisal systems used in Czech agricultural companies.

The findings of this study that Workers' Performance Pay affects CFP positively are concordant with some of the previously mentioned studies. In the sample, the effect of share of variable outcomes-based compensation occurs only in the companies pursuing the Differentiation strategy. The effect intensifies in non-exporting companies and companies with FDI. Various authors chose to control for the effect of different endogenous (e.g. Frick et al., 2013: age, teamwork, training) and exogenous variables (e.g. Battisti, Vallanti, 2013: local unemployment). These findings confirm that the contingency approach leads to more precise results.

\subsection{Strategy}

The effect of a chosen strategy on company performance has drawn attention for decades. For instance, Dess and Davis (1984) found that the most efficient strategies include Overall Low Cost followed by Differentiation, with Focus being the last. However, the usual research design over the years increasingly reflected the finding that the relationship between strategy and performance should be examined from the perspective of their compliance with various other characteristics of a company's internal and external environment. White came to the conclusion in 1986 that what contributes most to the growth of ROI is low autonomy in companies pursuing the LowCost strategy, and high coordination in companies pursuing the Differentiation strategy. In 2009, Leitner and Güldenberg (2009) work with the ownership type and share of exports as control variables when examining the effect of a chosen strategy on performance.

Shinkle, Kriaciunas, and Hundley (2013) or even Karabag and Berggren (2014) note that most studies on the topic of strategy and corporate performance come from the USA. Shinkle et al. (2013) also demonstrates that "benefits of a pure strategy are 
diminished when the institutional environment has a low degree of market orientation but are increased when the institutional environment is more market oriented." Thus, the results from a significantly different market may not be entirely valid in other market conditions. Therefore, the way a strategy affects performance may be significantly different in the Czech conditions; moreover, the effect of the chosen strategy may have varied significantly during the transformation of the Czech economy. In addition, not many studies examine the effect of a strategy on corporate performance in the Czech Republic. The closest in terms of the object of investigation are Skokan, Pawliczek, and Piszczur (2013) proving that companies with a "detailed written strategy" are more efficient than companies without a written strategy, or with a "written, but only concise" strategy, and Tripes, Kral, and Zelena (2013) testing generic strategies in terms of the sustainability of a competitive advantage for small sports clubs.

The zero-order relationship between the Strategy pursued and CFP is partly consistent with the findings by Dess and Davis (1984) that a business can best achieve sales growth by the Focus strategy, or with findings by Karabag and Berggren (2014) that the Differentiation strategy is more successful than the Low-Cost strategy. Nandakumar, Ghobadian, and O'Regan (2010) find a statistically insignificant negative correlation between the Cost Leadership strategy and performance for the zero-order relationship, as well as a statistically insignificant positive correlation between the Differentiation strategy and performance. As in this paper, these authors call for considering other variables and in fact confirm the effect of contextual factors.

An ambiguous effect of Strategy on CFP in this sample is modified as follows. Businesses without the presence of FDI are not effective in pursuing the Cost Leadership strategy; on the contrary, they are more effective pursuing the strategies of Cost Focus and especially Differentiation Focus, that is the Focus strategies in general, as well as the Differentiation strategies. Conversely, companies with FDI find pursuing the Cost Leadership strategy effective but certainly not Differentiation Focus. From the perspective of the strategies pursued, no changes occur in non-exporting companies, while exporting companies perform relatively worse when implementing both the Differentiation strategies they apparently do not pay off compared with the non-exporting companies. When combining the effect of the Export and FDI aspects on the pursued Strategy, the effect of FDI prevails. However, adding the effect of Export means increasing efficiency of the Cost Leadership strategy in exporting companies with FDI. Furthermore, the combined effect of Export and FDI increases the efficiency of the Focus strategies in exporting companies without FDI as well as the success rate of the Differentiation strategies, but the combination also reduces the efficiency of the Cost strategies in non-exporting companies without FDI. Non-exporting companies with FDI are almost absent.

The non-exporting companies focus on those strategies that are less successful more frequently than the exporting ones; despite this orientation, the overall effect of Export in the full sample is opposite: exporting companies have lower average CFP ( $m=0.45$ versus $m=0.18 ; p=0.02$ ).

The following table summarizes statistically significant zero- and first- order effects on CFP described in the text above. Second-order effects are discussed in the text only. 
Table 3 | Summary of Statistically Significant Zero- and First-Order Effects on CFP

\begin{tabular}{|c|c|c|c|c|}
\hline Independent variable & Subset & Direction & Effect size & p-value \\
\hline \multirow{3}{*}{ FDI } & Full sample & None & & \\
\hline & $\begin{array}{l}\text { Differentiation Focus } \\
\text { strategy }\end{array}$ & Negative & 0.21 & 0.05 \\
\hline & Both focussed strategies & Negative & 0.16 & 0.06 \\
\hline \multirow{7}{*}{ Export } & Full sample & Negative & 0.12 & 0.02 \\
\hline & Differentiation strategy & Negative & 0.18 & 0.08 \\
\hline & $\begin{array}{l}\text { Differentiation Focus } \\
\text { strategy }\end{array}$ & Negative & 0.19 & 0.07 \\
\hline & Both focussed strategies & Negative & 0.14 & 0.09 \\
\hline & $\begin{array}{l}\text { Both } \\
\text { Differentiation strategies }\end{array}$ & Negative & 0.13 & 0.08 \\
\hline & TMPP Above average & Negative & 0.13 & 0.10 \\
\hline & WPP Above average & Negative & 0.13 & 0.10 \\
\hline \multirow{3}{*}{$\begin{array}{l}\text { Share of Top } \\
\text { Management } \\
\text { Performance Pay on total } \\
\text { remuneration }\end{array}$} & Full sample & None & & \\
\hline & Cost Focus Strategy & Negative & -0.30 & 0.03 \\
\hline & Both Cost strategies & Negative & -0.14 & 0.10 \\
\hline \multirow{5}{*}{$\begin{array}{l}\text { Share of Workers' } \\
\text { Performance Pay on total } \\
\text { remuneration }\end{array}$} & Full sample & None & & \\
\hline & $\begin{array}{l}\text { Both not focussed } \\
\text { strategies }\end{array}$ & Positive & 0.16 & 0.05 \\
\hline & $\begin{array}{l}\text { Both Differentiation } \\
\text { strategies }\end{array}$ & Positive & 0.13 & 0.10 \\
\hline & Export no & Positive & 0.21 & 0.07 \\
\hline & TMPP above average & Positive & 0.17 & 0.03 \\
\hline \multirow{4}{*}{ Strategy (generic) } & Full sample & $\begin{array}{l}\text { Differentiation Focus } \\
\text { perform better than } \\
\text { Differentiation and } \\
\text { Cost Leadership }\end{array}$ & 0.15 & 0.04 \\
\hline & FDI no & $\begin{array}{l}\text { Differentiation Focus } \\
\text { perform better than } \\
\text { Differentiation and } \\
\text { Cost Leadership }\end{array}$ & 0.28 & 0.01 \\
\hline & TMPP below average & $\begin{array}{l}\text { Cost Focus perform } \\
\text { better than Cost } \\
\text { Leadership }\end{array}$ & 0.22 & 0.06 \\
\hline & WPP below average & $\begin{array}{l}\text { Cost Leadership } \\
\text { perform worse than } \\
\text { Cost Focus and } \\
\text { Differentiation Focus }\end{array}$ & 0.20 & 0.06 \\
\hline
\end{tabular}




\begin{tabular}{|c|c|c|c|c|}
\hline Independent variable & Subset & Direction & Effect size & p-value \\
\hline \multirow{5}{*}{ Strategy Focus Yes/No } & Full sample & $\begin{array}{l}\text { Focussed strategy } \\
\text { performs better }\end{array}$ & 0.13 & 0.01 \\
\hline & FDI no & $\begin{array}{l}\text { Focussed strategy } \\
\text { performs better }\end{array}$ & 0.25 & 0.01 \\
\hline & Export yes & $\begin{array}{l}\text { Focussed strategy } \\
\text { performs better }\end{array}$ & 0.12 & 0.05 \\
\hline & TMPP below average & $\begin{array}{l}\text { Focussed strategy } \\
\text { performs better }\end{array}$ & 0.18 & 0.03 \\
\hline & WPP below average & $\begin{array}{l}\text { Focussed strategy } \\
\text { performs better }\end{array}$ & 0.20 & 0.01 \\
\hline \multirow{3}{*}{$\begin{array}{l}\text { Strategy Differentiation/ } \\
\text { Cost }\end{array}$} & Full sample & None & & \\
\hline & FDI no & $\begin{array}{l}\text { Both Differentiation } \\
\text { strategies perform } \\
\text { better }\end{array}$ & 0.14 & 0.03 \\
\hline & Export no & $\begin{array}{l}\text { Both Differentiation } \\
\text { strategies perform } \\
\text { better }\end{array}$ & 0.20 & 0.08 \\
\hline
\end{tabular}

Note: TMPP stands for the Share of Top Management Performance Pay on total remuneration. WPP stands for the Share of Workers' Performance Pay on total remuneration.

Source: Author's calculations.

\section{Conclusion}

By conducting even a brief search one can find out that the topic of corporate performance is very comprehensive. Various authors have formulated and confirmed a range of corporate performance factors; these factors may come from the macro environment, micro environment or from within a company. They can be both tangible and intangible, and even their character can be important - whether they are rare, reproducible etc. However, what is really crucial is that they act together and in mutual, complex contexts. These interrelationships pose a big challenge for quantitative methods of searching for their effects. It is difficult for commonly used methods to cope with nonlinearity, multicollinearity and high dimensionality. These obstacles can be overcome partially with thorough elaboration; however, its labour intensity increases exponentially with the increasing dimensionality of the problem. For these reasons, the presented study uses the DAF algorithm in combination with a non-linear regression model to limit a large set of variables potentially affecting the corporate performance to only those variables that affect the corporate performance most. Thus, the DAF algorithm deals with high dimensionality while the non-linear regression model enables to capture complex moderated or partial effects of the subsets of variables being evaluated. A disadvantage is that this combination cannot determine how a given subset of variables affects the dependent variable. Nevertheless, this article presents a utilization of elaboration techniques, which are possible to use after reducing the set of variables. 
Thus, this paper brings benefits at two levels: the first benefit is the expansion of knowledge of the corporate performance factors in the Czech Republic. Although the sample characteristics (joint-stock companies and private limited companies from the manufacturing and construction industries employing 50 or more people) limit this contribution, the Czech environment does not provide so many studies dealing quantitatively with the corporate performance factors. The second level of benefits is at the methodical level: the analysed performance factors either do not show any zero-order relationships towards corporate performance, or their factual significance is very weak. Yet, closer inspection finds moderately strong relationships but usually another variable moderates them or these effects occur only in a specific subset of companies. These results confirm the thesis of the synergic effect of the corporate performance factors, and prove the combination of the DAF algorithm, non-linear regression model, and subsequent elaboration correct.

Regarding the expansion of knowledge, in companies pursuing the Cost Leadership strategy, the effect of the FDI presence in a company is strongly positive, whereas this effect is negative in companies pursuing the Differentiation strategy. This difference means that foreign owners are more successful in transferring their know-how and exploiting the advantages of the Czech Republic when using the strategies with lower added value rather than those with higher added value. The effects of Export are very negative in companies pursuing the Differentiation strategy, and negative in companies with the Differentiation Focus and Cost Leadership strategies. Therefore, Czech companies (or, more precisely, companies based in the Czech Republic) are incapable of competing in foreign markets when using these strategies despite the fact that the Differentiation Focus strategy is the most successful strategy in the whole sample. Deeper analyses suggest that a negative effect of transfer prices occurs within concerns. The effect of Performance Pay for managers is positive in exporting companies pursuing the Differentiation Focus strategy, and in non-exporting companies pursuing the Differentiation strategy. In all companies pursuing the Cost Leadership and Cost Focus strategies, the effect of Performance Pay for managers is negative, and in non-exporting companies the effect is highly negative. Thus, in companies pursuing the Cost strategies the negative cost effects associated with the variable wage component may outweigh the positive effects that this variable component brings. The effect of Performance Pay for workers is weak and positive and is limited to the companies that do not pursue the Focus strategies, companies pursuing the Differentiation strategies, and non-exporting companies. When combining these criteria, the positive effect is stronger. Therefore, companies seeking to compete by offering higher added value should find motivating their workers through Performance Pay worthwhile. Other analyses mentioned above show that these companies tend to perform better on the domestic market.

The Focus strategies are more successful than the other two strategies. On the contrary, neither Cost nor Differentiation strategies dominate the others. However, a clear finding is that contextual factors strongly determine the success or failure of a chosen Strategy. In foreign markets, the surveyed companies with the Differentiation strategies are significantly less 
successful, while companies pursuing the Cost strategies are more successful. In addition, companies without FDI perform worse when pursuing the Cost Leadership strategy but better with the other strategies; conversely, companies with FDI pursuing the Cost Leadership strategy perform better. An explanation might be that companies pursuing Cost strategies usually realize large volumes, which allows them to better recover sunk costs when entering foreign markets. When using the Differentiation strategies, companies may be able to accommodate their customers' wishes better in the domestic market than in the foreign markets. Foreign capital is then likely to be more effective in the Cost strategies where the FDI may help secure greater realized volumes, for example within concerns or in other markets etc.

Nevertheless, this study also suffers from several limits. Its foremost advantage should be combining predictors of performance from very different areas and investigating their combined or interrelated effects. This calls primarily for gathering a large amount of data leading to a lower number of companies willing to cooperate in such a survey. In our case, 432 companies were originally described by up to 500 variables (see Blažek, 2007). The DAF algorithm was fed with 75 of them (see the justification in Pudil et al., 2014, pp. 11-15). In this paper, the author interpreted the effects of only the five variables that predict corporate performance best; yet, this meant working with sub-samples of size less than 10 observations in some cases. Therefore, the first limit is the sample size. Another limitation is closely related: one could argue that once Strategy is considered a potential predictor of performance, its measurement should not be limited to Porter's generic strategies, or that other closely related organisation characteristics (e.g. organizational structure) should be examined as well. However, this would lead to an even higher number of variables or their categories, while the former leads to lower willingness of companies to cooperate and the latter to further splitting of the sample while seeking interpretation.

The contribution of this paper has to be specified in relation to previous publications on this topic. As mentioned above in the Introduction, the analyses presented here use data collected in the project carried out by RCCCE during 2005-2011 and an output of an algorithm developed in the GA CR Project during 2012-2014. Its value added comes from an in-depth elaboration and interpretation of the factors with the highest ability to predict corporate performance. Pudil et al. (2014) use for this purpose a series of linear regressions (pp. 91-128) and cluster analyses (pp. 129-154), which allows for a higher number of interpreted factors; on the other hand, it prevents investigating the subtle higherorder effects examined here.

\section{References}

Abor, J., Biekpe, N. (2007). Corporate Governance, Ownership Structure and Performance of SMEs in Ghana: Implications for Financing Opportunities. Corporate Governance: The International Journal of Business in Society, 7(3), 288-300, https://doi. org/10.1108/14720700710756562 
Andrews, R., Boyne, G. A. (2010). Capacity, Leadership, and Organizational Performance: Testing the Black Box Model of Public Management. Public Administration Review, 70(3), 443-454, https://doi.org/10.1111/j.1540-6210.2010.02158.x

Artiach, T., Lee, D., Nelson, D., Walker, J. (2010). The Determinants of Corporate Sustainability Performance. Accounting and Finance: Journal of the Accounting Association of Australia and New Zealand, 50(1), 31-51, https://doi.org/10.1111/j.1467-629X.2009.00315.x

Banker, R. D., Lee, S.-Y., Potter, G., Srinivasan, D. (1996). Contextual Analysis of Performance Impacts of Outcome-Based Incentive Compensation. Academy of Management Journal, 39(4), 920-948, https://doi.org/10.2307/256717

Battisti, M., Vallanti, G. (2013). Flexible Wage Contracts, Temporary Jobs, and Firm Performance: Evidence from Italian Firms. Industrial Relations: A Journal of Economy \& Society, 52(3), 737-764, https://doi.org/10.1111/irel.12031

Blažek, L., Částek, O. (2009). Stakeholder Approach and the Corporate Financial Performance. Review of Economic Perspectives, 9(2), 90-106, https://doi.org/10.2478/v10135-009-0002-7

Blažek, L., Částek, O., Gregorová, I., Karpissová, E., Kašparová, K., Klapalová, A., Kubátová, E., Pirožek, P., Suchánek, P., Svoboda, M., Šedová, J., Špalek, J. (2007). Konkurenční schopnost podniků: (primární analýza výsledků empirického šetřeni) (Competitiveness of Companies: Primary Analysis of Empirical Survey Results). Brno: Masarykova univerzita. ISBN 978-80-210-4456-2.

Blažek, L., Částek, O., Kubátová, E., Odehnalová, P., Pudil, P., Somol, P., Šiška, L., Špalek, J. (2008). Konkurenční schopnost podniků: (analýza faktorů hospodářské úspěšnosti) (Competitiveness of Companies. Analysis of Factors of Economical Success). Brno: Masarykova univerzita. ISBN 978-80-210-4734-1.

Botek, M., Pecháčová, E. (2013). Using the Balanced Scorecard Concept for Employee Remuneration. Ekonomicka Revue: Central European Review of Economic Issues, 16(3), 169-182, https://doi.org/10.7327/cerei.2013.09.06

Cagwin, D., Barker, K. J. (2006). Activity-Based Costing, Total Quality Management and Business Process Reengineering: Their Separate and Concurrent Association with Improvement in Financial Performance. Academy of Accounting and Financial Studies Journal, 10(1), 49.

Částek, O. (2013). The Effect of Ownership Structure on Corporate Financial Performance in the Czech Republic. Proceedings of the European Conference on Management, Leadership \& Governance, 7.

Čerović, S., Stanišić, N., Radojević, T., Radović, N. (2015). The Impact of Ownership Structure on Corporate Performance in Transitional Economies. Amfiteatru Economic, 17(38), 441-454.

Clerides, S. K., Lach, S., Tybout, J. R. (1998). Is Learning by Exporting Important? Micro-Dynamic Evidence from Colombia, Mexico, and Morocco. The Quarterly Journal of Economics, 113(3), 903-947, https://doi.org/10.1162/003355398555784

Czinkota, M. R., Ronkainen, I. A. (1998). International Marketing. 5th Edition. Fort Worth: Dryden Press. Available at: http://trove.nla.gov.au/version/46663231. ISBN 0-03-024401-3.

Damiani, M., Ricci, A. (2008). Flexible Wage Contracts, and Firm Productivity: Evidence from Italy. Italian Association of Labour Economics, Brescia, Italy, 26. Available at: http://www.aiel.it/ Old/bacheca/BRESCIA/papers/damiani_ricci.pdf

Dess, G. G., Davis, P. S. (1984). Porter's (1980) Generic Strategies as Determinants of Strategic Group Membership and Organizational Performance. Academy of Management Journal, 27(3), 467-488, https://doi.org/10.2307/256040 
Djankov, S., Hoekman, B. (2000). Foreign Investment and Productivity Growth in Czech Enterprises. The World Bank Economic Review, 14(1), 49-64, https://doi.org/10.1093/wber/14.1.49

Frick, B. J., Goetzen, U., Simmons, R. (2013). The Hidden Costs of High-Performance Work Practices: Evidence from a Large German Steel Company. ILR Review:

A Publication of the New York State School of Industrial and Labor Relations, a Statutory College of the State University, Cornell University, Ithaca, 66(1), 198-224, https://doi. org/10.1177/001979391306600108

Garcia-Fuentes, P. A., Ferreira, G. F. C., Kennedy, P. L. (2013). Economic Performance of U. S. Multinational Agribusinesses: Foreign Direct Investment and Firm Strategy. Agribusiness, 29(2), 242-255, https://doi.org/10.1002/agr.21316

Gielen, A., Kerkhofs, M., van Ours, J. (2010). How Performance Related Pay Affects Productivity and Employment. Journal of Population Economics, 23(1), 291-301, https://doi.org/ $10.1007 / \mathrm{s} 00148-009-0252-9$

Hansen, G. S., Wernerfelt, B. (1989). Determinants of Firm Performance: The Relative Importance of Economic and Organizational Factors. Strategic Management Journal, 10(5), 399-411, https://doi.org/10.1002/smj.4250100502

Harumová, A., Janisová, M. (2014). Hodnotenie slovenských podnikov pomocou skóringovej funkcie (Rating Slovak Enterprises by Scoring Functions). Ekonomický časopis: Časopis pre ekonomickú teóriu, hospodársku politiku, spoločensko-ekonomické prognózovanie, 62(5), 522-539.

Hradecká, I. (1995). Výrobní dělníci, industriální vztahy a sociální politika: Základní orientace a postoje (Workers, Industrial Relations and Social Politics: General Orientations and Attitudes). Sociologický Časopis /Czech Sociological Review, (4), 485-499.

Hult, G. T. M., Ketchen, D. J., Griffith, D. A., Chabowski, B. R., Hamman, M. K., Dykes, B. J., Pollitte, W. A., Cavusgil, S. T. (2008). An Assessment of the Measurement of Performance in International Business Research. Journal of International Business Studies, 39(6), 1064 1080, https://doi.org/10.1057/palgrave.jibs.8400398

Jurajda, Š., Stančík, J. (2009). Foreign Ownership and Corporate Performance: The Czech Republic at EU Entry. CERGE-El. Working Paper Series No. 389, 1-34, https://doi.org/10.2139/ ssrn. 1480745

Karabag, S. F., Berggren, C. (2014). Antecedents of Firm Performance in Emerging Economies: Business Groups, Strategy, Industry Structure, and State Support. Journal of Business Research, 67(10), 2212-2223, https://doi.org/10.1016/j.jbusres.2014.01.004

Kessler, A. (2007). Success Factors for New Businesses in Austria and the Czech Republic. Entrepreneurship \& Regional Development, 19(5), 381-403, https://doi. org/10.1080/08985620701439959

Kirby, J. (2005). Toward a Theory of High Performance. Harvard Business Review, 83(7), 30-39.

Kočenda, E., Švejnar, J. (2003). Ownership and Firm Performance after Large-Scale Privatization. CERGE-El. Prague Working Paper Series No. 209. ISBN 80-86286-97-5.

Lazear, E. P. (2000). Performance Pay and Productivity. American Economic Review, 90(5), 1346-1361, https://doi.org/10.1257/aer.90.5.1346

Lee, J., Habte-Giorgis, B. (2004). Empirical Approach to the Sequential Relationships between Firm Strategy, Export Activity, and Performance in U.S. Manufacturing Firms. International Business Review, 13(1), 101-129, https://doi.org/10.1016/j.ibusrev.2003.05.003

Leitner, K. H., Güldenberg, S. (2010). Generic Strategies and Firm Performance in SMEs: A Longitudinal Study of Austrian SMEs. Small Business Economics, 35(2), 169-189, https://doi.org/10.1007/s11187-009-9239-x 
Makri, M., Lane, P. J., Gomez-Mejia, L. R. (2006). CEO Incentives, Innovation, and Performance in Technology-Intensive Firms: A Reconciliation of Outcome and Behavior-Based Incentive Schemes. Strategic Management Journal, 27(11), 1057-1080, https://doi.org/10.1002/smj.560

Moini, H., Kalouda, F., Tesar, G. (2008). Foreign Market Entry: The Case of SMEs in the Czech Republic. Journal of East-West Business, 14(1), 41-64, https://doi.org/10.1300/ J097v14n01_03

Molina, M. A., del Pino, I. B., Rodríguez, A. C. (2004). Industry, Management Capabilities and Firms' Competitiveness: An Empirical Contribution. Managerial \& Decision Economics, 25(5), 265-281, https://doi.org/10.1002/mde.1148

Nandakumar, M. K., Ghobadian, A., O’Regan, N. (2010). Business-Level Strategy and Performance. Management Decision, 48(6), 907-939, https://doi. org/10.1108/00251741011053460

Paarsch, H. J., Shearer, B. S. (1999). The Response of Worker Effort to Piece Rates: Evidence from the British Columbia Tree-Planting Industry. The Journal of Human Resources, 34(4), 643-667, https://doi.org/10.2307/146411

Paligorova, T. (2007). Corporate Governance and Executive Pay: Evidence from a Recent Reform. CERGE-EI. Prague Working Paper Series No. 331. ISBN 978-80-7343-130-3.

Pokorná, J. (2012). Finanční výkonnost českých podniků se zahraničním kapitálem (Financial Performance of Czech Companies with Foreign Capital). Trendy ekonomiky a managementu, 6(11), 27-34.

Pokorná, J., Částek, O. (2013). How to Measure Organizational Performance in Search for Factors of Competitiveness. Acta Universitatis Agriculturae et Silviculturae Mendelianae Brunensis, 61(2), 451-461, https://doi.org/10.11118/actaun201361020451

Pudil, P., Blažek, L., Somol, P., Částek, O., Grim, J. (2013). Identification of Corporate Competitiveness Factors - Comparing Different Approaches. Proceedings of the International Conference on Management, Leadership \& Governance, 259-267.

Pudil, P., Blažek, L., Částek, O., Somol, P., Pokorná, J., Králová, M. (2014). Identifying Corporate Performance Factors Based on Feature Selection in Statistical Pattern Recognition: Methods, Application, Interpretation. Brno: Faculty of Economics and Administration, Masaryk University. ISBN 978-80-210-7557-3, https://doi.org/10.5817/CZ.MUNI.M210-7557-2014

Reed, R., De Fillippi, R. (1990). Causal Ambiguity, Barriers to Imitation, and Sustainable Competitive Advantage. Academy of Management Review, 15(1), 88-102, https://doi. org/10.5465/amr.1990.4308277

Richard, P., Devinney, T., Yip, G., Johnson, G. (2009). Measuring Organizational Performance: Towards Methodological Best Practice. Journal of Management, 35(3), 718-804, https://doi.org/ 10.1177/0149206308330560

Roubickova, M., Heryan, T. (2014). Impacts of Selected NACE Industries Foreign Ownership on the Czech Economy. Ekonomie a Management, 17(4), 58-69, https://doi.org/10.15240/ tul/001/2014-4-005

Saxa, B. (2008). Exporting Behavior of Firms: How Do Multinationals Change International Trade? CERGE-El, 882(21). Available at: https://www.cerge-ei.cz/pdf/gdn/rrc/RRCVI_20_paper_01.pdf

Sedláková, I. (2014). Testing the Success of Prediction Models. Forum Statisticum Slovacum, 10(4), 160-165.

Shinkle, G. A., Kriauciunas, A. P., Hundley, G. (2013). Why Pure Strategies May be Wrong for Transition Economy Firms. Strategic Management Journal, 34(10), 1244-1254, https://doi.org/ 10.1002/smj.2060 
Šiška L., Lízalová L. (2011). Výběr ekonomických ukazatelů pro měření dlouhodobé výkonnosti podniku. (anglicky). Journal of Competitiveness, (1), 4.

Skokan, K., Pawliczek, A., Piszczur, R. (2013). Strategic Planning and Business Performance of Micro, Small and Medium-Sized Enterprises. Journal of Competitiveness, 5(4), 57-72, https://doi.org/ 10.7441/joc.2013.04.04

Somol, P., Pudil, P., Částek, O., Pokorná, J. (2014). Improved Model for Attribute Selection on HighDimensional Economic Data. Proceedings of the International Conference on Management, Leadership \& Governance, 276-285.

Spalek, J., Částek, O. (2010). Contribution of Statistical Pattern Recognition Methods in Search of Competitiveness Factors of Czech Companies. Ekonomicky casopis, 58(9), 922-937.

Tripes, S., Kral, P., Zelena, V. (2013). Proper Strategy Selection as Essential Survival Prerequisite for Small Sport Clubs. Proceedings of the European Conference on Management, Leadership \& Governance, 308-316.

Upneja, A., Ozdemir, O. (2014). Compensation Practices in the Lodging Industry: Does Top Management Pay Affect Corporate Performance? International Journal of Hospitality Management, 38, 30-38, https://doi.org/10.1016/j.ijhm.2013.12.007

Venclová, K., Königová, M., Fejfar, J. (2013). Current State of the Employee Performance Appraisal System in Agricultural Organizations in the Czech Republic. Acta Universitatis Agriculturae et Silviculturae Mendelianae Brunensis, 61(4), 1183-1189, https://doi. org/10.11118/actaun201361041183

Weiss, A., Nikitin, G. A. (2004). Foreign Portfolio Investment Improves Performance: Evidence from the Czech Republic. Topics in Economic Analysis and Policy, 4(1), 1-47, https://doi. org/10.2202/1538-0653.1205

White, R. E. (1986). Generic Business Strategies, Organizational Context and Performance: An Empirical Investigation. Strategic Management Journal, 7(3), 217-231, https://doi. org/10.1002/smj.4250070304

World Bank (1993). The East Asian Miracle. A World Bank Policy Research Report. New York: Oxford University Press. ISBN 0-19-520993-1.

Yilmaz, C., Alpkan, L., Ergun, E. (2005). Cultural Determinants of Customer- and LearningOriented Value Systems and Their Joint Effects on Firm Performance. Journal of Business Research, 58(10), 1340-1352, https://doi.org/10.1016/j.jbusres.2004.06.002

Zemplinerová, A. (1998). Impact of Foreign Direct Investment on the Restructuring and Growth in Manufacturing. Prague Economic Papers, 7(4), 329-345, https://doi.org/10.18267/j. pep.159 